\title{
Effect of selective $\mathrm{ET}_{\mathrm{A}}$ receptor blockade on natriuretic peptide gene expression in DOCA-salt hypertension
}

\author{
LILIANA G. BIANCIOTTI AND ADOLFO J. DE BOLD \\ University of Ottawa Heart Institute and the Department of Pathology and Laboratory Medicine, \\ Faculty of Medicine, University of Ottawa, Ottawa, Ontario, Canada K1Y 4W7
}

Received 24 September 1999; accepted in final form 5 January 2000

\begin{abstract}
Bianciotti, Liliana G., and Adolfo J. de Bold. Effect of selective $\mathrm{ET}_{\mathrm{A}}$ receptor blockade on natriuretic peptide gene expression in DOCA-salt hypertension. Am $J$ Physiol Heart Circ Physiol 279: H93-H101, 2000.-To determine the role of endothelin-1 (ET-1) in the upregulation of atrial natriuretic factor $(\mathrm{ANF})$ and brain natriuretic peptide $(\mathrm{BNP})$ observed in deoxycorticosterone acetate (DOCA)-salt hypertension, the selective ET-1 type-A receptor $\left(\mathrm{ET}_{\mathrm{A}}\right)$ antagonist $\mathrm{ABT}-627$ was chronically administered to normal controls and hypertensive rats. Chronic $\mathrm{ET}_{\mathrm{A}}$ blockade in DOCA-salt-treated rats prevented the increase in blood pressure and circulating natriuretic protein (NP) levels and partially prevented left ventricular hypertrophy. The changes observed in NP gene expression in the atria were not affected by ABT-627. In the ventricles, ABT-627 reduced NP gene expression. Rats receiving the $\mathrm{ET}_{\mathrm{A}}$ antagonist alone showed reduced left ventricular NP gene expression. ABT-627 did not affect ventricular collagen III gene expression but enhanced left ventricular $\alpha$-myosin heavy chain expression. These findings suggest that in vivo, ventricular but not atrial NP production is regulated by ET-1. This difference in response between atrial and ventricular NP gene expression to $\mathrm{ET}_{\mathrm{A}}$ receptor blockade is similar to that observed by us after applying angiotensin-converting enzyme inhibitors in other hypertensive models. In general therefore, atrial NP gene expression may not be as sensitive to the endocrine environment as is ventricular NP gene expression.
\end{abstract}

atrial natriuretic factor; brain natriuretic peptide; ABT-627; endothelin; hypertrophy

DEOXYCORTICOSTERONE ACETATE (DOCA)-salt treatment powerfully stimulates cardiac gene expression of the natriuretic peptides (NP), atrial natriuretic factor (ANF), and brain natriuretic peptide (BNP) $(9,25)$. Short-term (1 wk) DOCA-salt administration leads to an increase in atrial NP gene expression, and a longer treatment ( $5 \mathrm{wk}$ ) leads to an increase in ventricular NP gene expression as well (25). The former effect is ascribed to volume expansion on stretch-stimulated gene expression, whereas the latter effect is believed to arise as a consequence of left ventricular hypertrophy and associated activation of the cardiac fetal program resulting from systemic hypertension. The mechanisms

\footnotetext{
Address for reprint requests and other correspondence: A. J. de Bold, Cardiac Cell and Molecular Laboratory, Univ. of Ottawa Heart Institute, 40 Ruskin St., Ottawa, ONT, Canada K1Y 4W7 (E-mail: adebold@ottawaheart.ca).
}

underlying these changes in NP gene expression and release remain unclear. We have previously shown that mechanical and neuroendocrine factors independently contribute to the modulation of ANF and BNP ventricular gene expression. This view was advanced based on the observation that in renovascular hypertension, a low dose of the angiotensin-converting enzyme (ACE) inhibitor ramipril reverses hypertrophy but does not decrease blood pressure and only partially prevents enhanced ventricular NP gene expression (16). These findings suggest that there are two components that contribute to increased ventricular NP gene expression: one occurs together with the hypertrophic process and is independent of load, and another one is dependent on hemodynamic load. Indeed, high-dose ramipril, which also regresses hypertrophy but in addition normalizes blood pressure, completely normalized ventricular NP gene expression. This investigation showed that atrial NP gene expression was not affected by chronic treatment (of control or hypertensive animals) with low- or high-dose ramipril, suggesting that atrial and ventricular NP gene expressions are differentially regulated (16).

Some of the effects of DOCA-salt treatment on NP gene expression may be expected to arise from the known activation of endothelin-1 (ET-1) in this hypertension model (12). ET-1, signaling through the type-A receptor $\left(\mathrm{ET}_{\mathrm{A}}\right)(24)$, induces significant changes in NP gene expression and release both in vitro and in vivo ( 1 , $2,22)$. These findings suggest that ET-1 may be a key factor in the maintenance of NP basal and stimulated gene expression and release.

In the present work, we studied the effect of the chronic blockade of the $\mathrm{ET}_{\mathrm{A}}$ receptor with a selective $\mathrm{ET}_{\mathrm{A}}$ antagonist, ABT-627, on NP gene expression and production in normal and DOCA-salt hypertensive rats, to assess the contribution of ET-1 in mediating basal and stimulated cardiac NP production in vivo. In addition, we determined the levels of genetic expression of $\alpha$ - and $\beta$-myosin heavy chains (MHC) and collagen III as independent molecular markers of hypertrophy for cardiocytes and connective tissue, respectively.

\footnotetext{
The costs of publication of this article were defrayed in part by the payment of page charges. The article must therefore be hereby marked "advertisement" in accordance with 18 U.S.C. Section 1734 solely to indicate this fact.
} 


\section{MATERIALS AND METHODS}

Male Sprague-Dawley rats weighing 100-125 g were housed under conditions of constant temperature and humidity, with a 12-h light/dark cycle, and fed ad libitum. All experiments were performed following the recommendations of the Canadian Council for Animal Care. DOCA-salt hypertension was induced with weekly subcutaneous injections of $30 \mathrm{mg} / \mathrm{kg}$ DOCA (Sigma) dissolved in sesame seed oil (as vehicle) and the administration of $1 \% \mathrm{NaCl}$ in the drinking water for $5 \mathrm{wk}$. We administered $10 \mathrm{mg} \cdot \mathrm{kg}^{-1} \cdot \mathrm{day}^{-1}$ ABT-627, the orally active enantiomer of the $\mathrm{ET}_{\mathrm{A}}$ blocker A-12722 (18), in the drinking water. The dose was adjusted daily based on water consumption and weight. After 5 wk, systolic blood pressure was measured in conscious rats by tail pletysmography (Narco Bio-Systems, Austin, TX), and the average of three pressure readings was recorded. The animals were killed by decapitation, and trunk blood samples were harvested into ice-cold tubes containing $0.1 \mathrm{ml}$ of $15 \%$ $\mathrm{K}_{3}$-EDTA. Blood samples were centrifuged at 2,000 $\mathrm{g}$ for 30 min at $4^{\circ} \mathrm{C}$, and plasmas were kept at $-80^{\circ} \mathrm{C}$ until assayed for immunoreactive $\mathrm{ANF}$ and BNP. The hearts were rapidly excised, and the four chambers were dissected, weighed, rapidly frozen in liquid nitrogen and kept at $-80^{\circ} \mathrm{C}$. The interatrial or interventricular septum was included with the respective left chamber.

Total RNA extraction and Northern blot analysis. Total RNA extraction and Northern blot analysis were performed as previously described (16, 25). Briefly, total RNA was extracted and electrophoretically separated in an agaroseformaldeyde gel followed by blotting to nylon membranes (Hybond $\mathrm{N}^{+}$, Amersham). Membranes were hybridized with cDNA and oligonucleotide probes as detailed in previous works $(16,25)$. The cDNA probes used were 1) a 900-bp EcoR I/Hind III fragment containing the full-length rat ANF cDNA, 2) a 595-bp Sal I fragment containing the full-length BNP cDNA, 3) a 5-kb EcoR I/Sal I fragment of the mouse 28S rRNA probe, 4) a 2-kb $B a m \mathrm{H} \mathrm{I} B g l$ II fragment of the mouse phosphoglycerate kinase (PGK) gene cDNA, and 5) rat $1 \alpha$ collagen III cDNA containing $1,300 \mathrm{bp}$ of the $3^{\prime}$ noncoding and coding regions. The two oligonucleotides used were 39and 24-base fragments specific for unique regions in the 3 ' untranslated regions of the rat $\alpha-\mathrm{MHC}$ and $\beta-\mathrm{MHC}$ genes.

The cDNAs were labeled with $5^{\prime}\left[\alpha-{ }^{32} \mathrm{P}\right] \mathrm{dCTP}(3,000 \mathrm{Ci} /$ mmol, Amersham) using the Megaprime DNA labeling system (Amersham). The oligonucleotides were labeled with $\left[\gamma^{32} \mathrm{P}\right] \operatorname{ATP}\left(3,000 \mathrm{Ci} / \mathrm{mmol}\right.$, Amersham) using a $5^{\prime}$ end-labeling kit (Amersham). Before additional probing, bound radioactivity was stripped from the membranes by washing with $10 \mathrm{mM}$ sodium citrate ( $\mathrm{pH} 6.8$ ) and $0.25 \% \mathrm{SDS}$ at $100^{\circ} \mathrm{C}$ for $10 \mathrm{~min}$. Autoradiographs were scanned using a laser densitometer, and the scanning values for ANF, BNP, collagen III, and MHC isoform mRNAs were normalized to 28S rRNA or PKG mRNA to correct for differences in the amount of RNA applied and for transfer efficiency.

Extraction and RIA for ANF and BNP in plasma and tissue samples. NP were extracted from plasma and tissue samples and assayed as previously described (16, 19, 20, 25). Anti-rat ANF-(99-126) and anti-rat BNP-(64-95) serum were purchased (Peninsula Laboratories, Belmont, CA) and showed $<0.01 \%$ cross-reactivity with BNP and ANF peptides, respectively.

Analysis of results. Data are expressed as means $\pm \mathrm{SE}$. Statistical analysis was performed by ANOVA; a $P$ value of 0.05 or less was considered statistically significant.

\section{RESULTS}

DOCA-salt-treated rats had a higher daily water intake than control rats. The incorporation of the $\mathrm{ET}_{\mathrm{A}}$ antagonist into the drinking water did not affect fluid intake. The $\mathrm{ET}_{\mathrm{A}}$ antagonist intake was $10.4 \pm 0.2 \mathrm{mg} \cdot$ $\mathrm{kg}^{-1} \cdot \mathrm{day}^{-1}$.

Systolic blood pressure, body weight, and heart chamber weight. Systolic blood pressure was significantly elevated in DOCA-salt-treated rats compared with control rats and those treated with the $\mathrm{ET}_{\mathrm{A}}$ antagonist (Table 1). Treatment with the $\mathrm{ET}_{\mathrm{A}}$ blocker normalized blood pressure to control levels in DOCAsalt-treated rats. $\mathrm{ET}_{\mathrm{A}}$ receptor blockade also reduced systolic blood pressure in the rats receiving the antagonist alone. Body weight did not differ among the four studied groups. The left ventricular weight-to-body weight ratio (relative left ventricular weight) in DOCAsalt hypertensive rats was increased compared with controls and $\mathrm{ET}_{\mathrm{A}}$-treated rats. DOCA-salt-treated rats that received the $\mathrm{ET}_{\mathrm{A}}$ blocker showed a partial reduction in relative left ventricular weight. No modification of the relative right ventricular weight was observed among the studied groups.

Cardiac $A N F$ and BNP gene expression. Figures 1 and 2 show cardiac NP gene expression in DOCA-salttreated rats with or without $\mathrm{ET}_{\mathrm{A}}$ receptor blockade. ANF gene expression was enhanced in the left atrium as well as in both ventricles of DOCA-salt-treated rats. BNP gene expression was increased in all the cardiac chambers in this group. The administration of the $\mathrm{ET}_{\mathrm{A}}$ blocker partially prevented the increase of ANF and BNP mRNA in the left ventricle, and totally prevented it in the right ventricle. Atrial NP gene expression was not affected by $\mathrm{ET}_{\mathrm{A}}$ receptor blockade. The group of animals that received the antagonist alone had reduced left ventricular ANF and BNP gene expression as compared with the control group.

$\alpha-M H C$ and $\beta-M H C$ gene expression. DOCA-salttreated rats exhibited a reduction in $\alpha$-MHC gene expression and an increase in $\beta$-MHC isoform in the left ventricle (Figs. 3 and 4). However, no MHC isoform switch was observed in the right ventricle. $\mathrm{ET}_{\mathrm{A}}$ receptor blockade enhanced $\alpha-\mathrm{MHC}$ expression but did not

Table 1. Effect of $E T_{A}$ receptor blockade on blood pressure, body weight, and relative ventricular weight in DOCA-salt-treated rats

\begin{tabular}{lcccc}
\hline \hline & & & & \\
& Control & DOCA-Salt & ABT-627 & $\begin{array}{c}\text { DOCA- } \\
\text { Salt+ABT- } \\
627\end{array}$ \\
\hline BP, mmHg & $117 \pm 2$ & $149 \pm 3 \dagger$ & $110 \pm 2^{*} \dagger$ & $120 \pm 2 \S$ \\
BW, g & $394 \pm 7$ & $396 \pm 8$ & $399 \pm 6$ & $396 \pm 7$ \\
LVW/BW & $2.05 \pm 0.05$ & $2.6 \pm 0.05 \dagger$ & $2.1 \pm 0.06$ & $2.4 \pm 0.06^{*} \S$ \\
RVW/BW & $0.76 \pm 0.03$ & $0.77 \pm 0.03$ & $0.77 \pm 0.02$ & $0.76 \pm 0.04$ \\
\hline
\end{tabular}

Values are means $\pm \mathrm{SE}$ of 12 independent observations. DOCA, deoxycorticosterone acetate; $\mathrm{ET}_{\mathrm{A}}$, endothelin-1 type-A receptor; ABT-627, $\mathrm{ET}_{\mathrm{A}}$ antagonist; $\mathrm{BP}$, systolic blood pressure; $\mathrm{BW}$, body weight; LVW/BW, relative left ventricular weight; RVW/BW, relative right ventricular weight. ${ }^{*} P<0.05$ vs. control; $\dagger P<0.001$ vs. control; $\ddagger P<0.05$ and $\S P<0.01$ vs. DOCA-salt. 
A

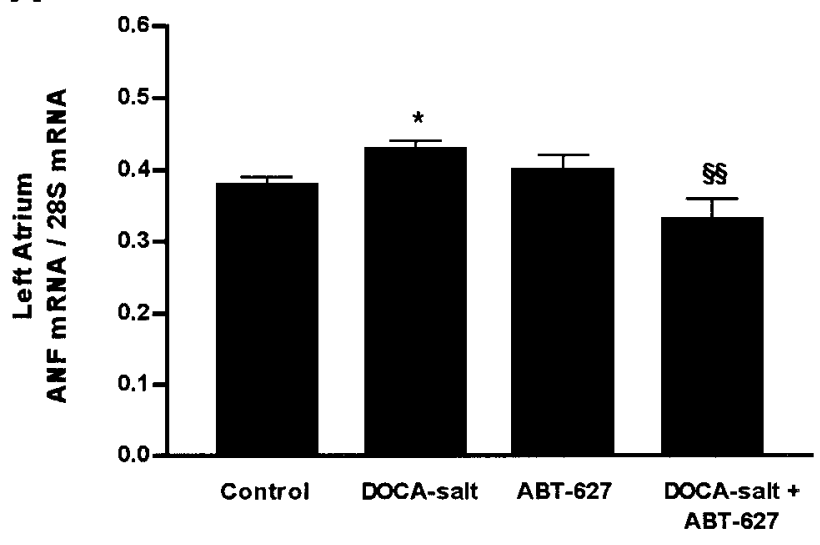

C

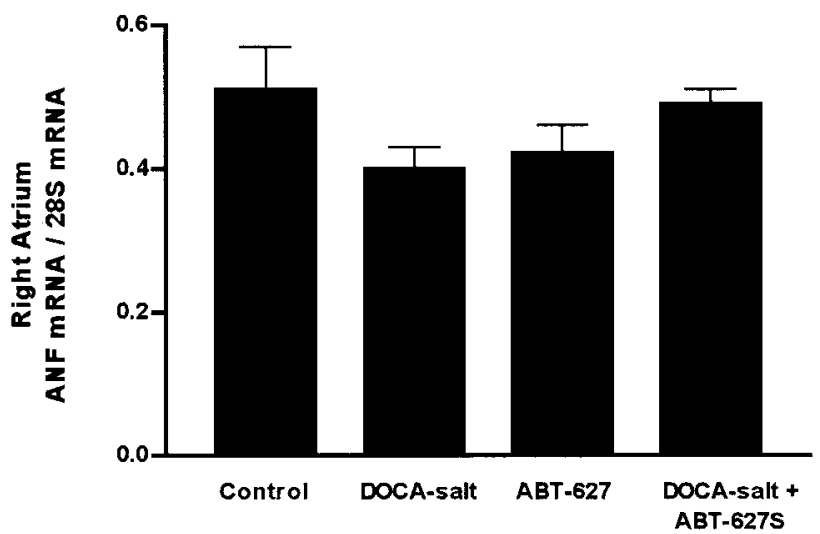

B

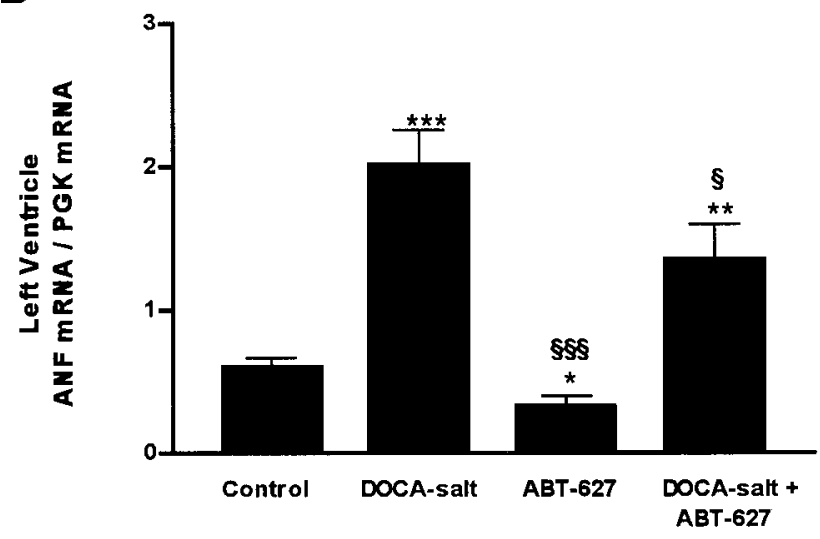

D

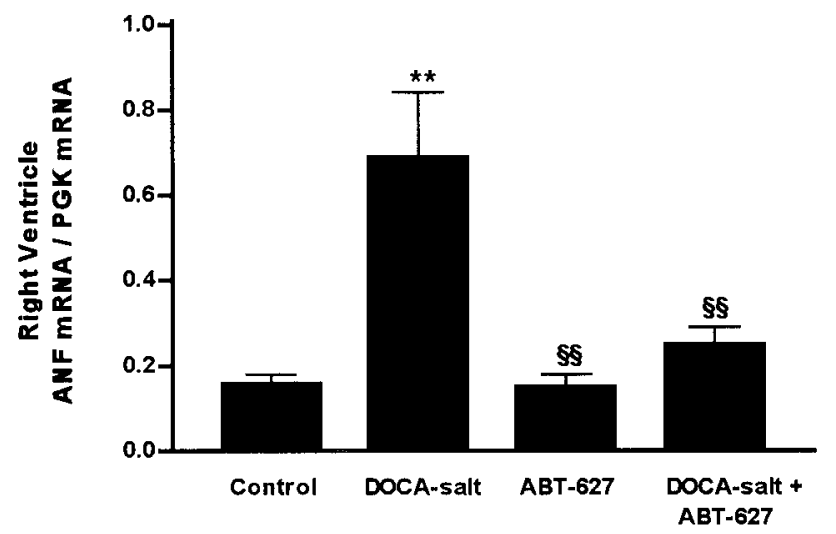

Fig. 1. Relative abundance of atrial natriuretic factor (ANF) transcripts in cardiac chambers after chronic endothelin type $\mathrm{A}\left(\mathrm{ET}_{\mathrm{A}}\right)$ receptor blockade $\left(10 \mathrm{mg} \cdot \mathrm{kg}^{-1} \cdot\right.$ day $^{-1}$ of ABT-627) in deoxycorticosterone acetate (DOCA)-salt hypertensive rats. PGK, phosphoglycerate kinase. $A$ : left atrium; $B$ : left ventricle; $C$ : right atrium; $D$ : right ventricle. Values are means $\pm \mathrm{SE}$. ${ }^{*} P<0.05$, $* * P<0.01$, and $* * * P<0.001$ vs. control; $\S P<0.05, \S \S P<0.01$, and $\S \S \S P<0.001$ vs. DOCA-salt ( $n=4-5$ rats).

modify the expression of the $\beta$-isoform in the left ventricle of DOCA-salt-treated rats or in the animals receiving only the antagonist (Fig. 4).

Collagen III gene expression. Collagen III mRNA, an index of de novo connective tissue matrix synthesis, was increased in the left ventricle of DOCA-salttreated rats but was not affected by the $\mathrm{ET}_{\mathrm{A}}$ receptor blockade. No change in collagen III expression was observed in the right ventricle in any of the groups (Fig. 5).

Immunoreactive ANF and BNP plasma levels. DOCAsalt treatment increased immunoreactive (ir) ANF and BNP plasma concentrations (Fig. 6). The increase in plasma BNP was significantly higher than that of ANF $(46 \%$ vs. $18 \%) . \mathrm{ET}_{\mathrm{A}}$ receptor blockade induced a significant reduction in plasma NP, this effect being most marked for BNP.

Cardiac tissue irANF and irBNP. DOCA-salt-treated rats exhibited a decrease in irANF in both right and left atria and an increase in both ventricles (Fig. 7). Treatment with ABT-627 reduced irANF in the right ventricle to control levels but did not affect the peptide content in the left ventricle or the atria. irBNP content was not altered in the atria but was increased in the right and left ventricles of DOCA-salt hypertensive rats (Fig. 8). Treatment with ABT-627 totally prevented the increase of irBNP in both ventricles.

\section{DISCUSSION}

The contribution of neuroendocrine factors to the long-term regulation of ANF and BNP gene expression in vivo remains poorly understood for both atria and ventricles. The release of these hormones from the atria is enhanced on stimulation by mechanical (muscle stretch) or neuroendocrine (e.g., ET-1) stimuli. Whether this stimulation results in an increase in NP gene expression depends upon the duration and the 
A



B

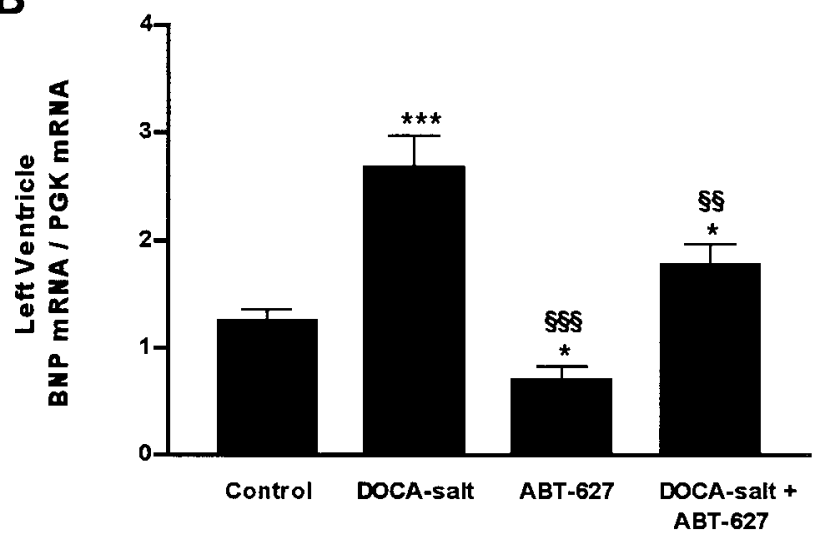

C

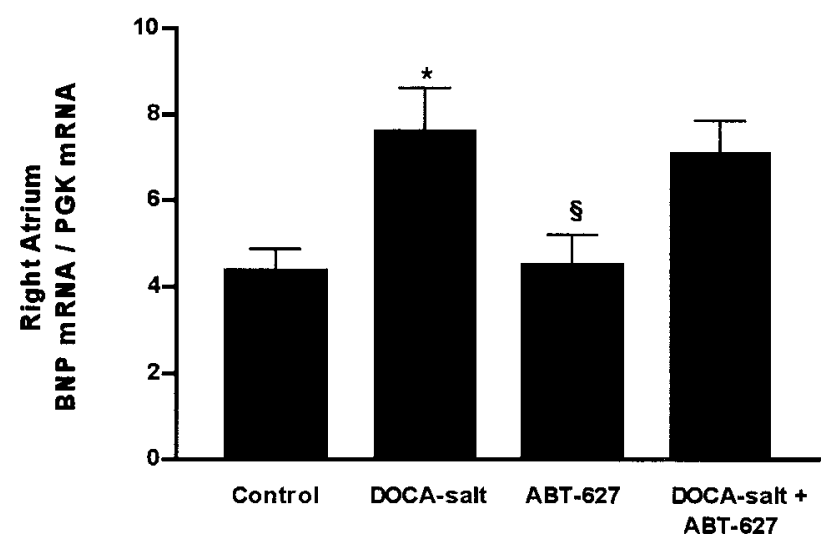

D

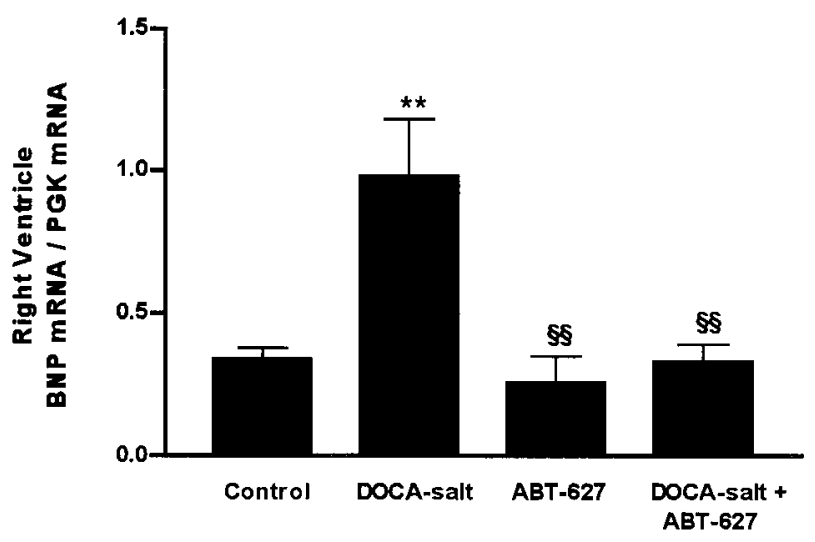

Fig. 2. Relative abundance of brain natriuretic peptide (BNP) transcripts in cardiac chambers after chronic $\mathrm{ET}_{\mathrm{A}}$ receptor blockade $\left(10 \mathrm{mg} \cdot \mathrm{kg}^{-1} \cdot \mathrm{day}^{-1}\right.$ of ABT-627) in DOCA-salt hypertensive rats. $A$ : left atrium; $B$ : left ventricle; $C$ : right atrium; $D$ : right ventricle. Values are means $\pm \mathrm{SE}$. $* P<0.05, * * P<0.01$, and $* * * P<0.001$ vs. control; $\S P<0.05, \S \S P<0.01$, and $\S \S \S P<0.001$ vs. DOCA-salt $(n=4-5)$.

nature of the stimuli $(1,25,26)$. For instance, DOCAsalt treatment for $1 \mathrm{wk}$ results in volume expansion and leads to upregulation of NP gene expression that is confined to the atria. In addition, 5 wk of DOCA-salt treatment leads to hypertension, anatomical left ventricular hypertrophy, and the activation of the cardiac fetal program in the ventricles, which includes the increased expression of genes encoding for $\alpha$-skeletal actin, ANF, and BNP, as well as to a switch in MHC isoforms $(3,21,25)$. Under these circumstances, BNP is particularly upregulated in the ventricles. In the atria, no MHC isoform switch is observed, despite the fact that ANF and BNP gene expression is upregulated, as is the case for the ventricles (25). In contrast, atrial $\mathrm{ANF}$ and BNP gene expression in renovascular hypertension remains unchanged, whereas ventricular expression does change in a manner that is partially dependent on both the hypertrophic process and the increase in hemodynamic load (25). These observations show that the regulation of NP in atria and ventricles differs significantly. In the present investigation, we sought to establish the contribution of ET-1 to atrial and ventricular NP gene expression in vivo through the use of the selective $\mathrm{ET}_{\mathrm{A}}$ receptor antagonist ABT627 in DOCA-salt hypertensive rats. The DOCA-salt model is known to be associated with upregulation of the endothelin system as well as the NP system (12, 25). The pharmacological characterization of ABT-627 has been previously reported (18). It was found that 10 $\mathrm{mg} \cdot \mathrm{kg}^{-1} \cdot$ day $^{-1}$ was an effective oral dose to block the effects elicited by ET-1 administration. Furthermore, the effects induced by higher doses $\left(30 \mathrm{mg} \cdot \mathrm{kg}^{-1}\right.$. day $^{-1}$ ) were similar to those observed with the use of $10 \mathrm{mg} \cdot \mathrm{kg}^{-1} \cdot$ day $^{-1}(18)$.

DOCA-salt treatment following the experimental design employed in the present work induced mild hypertension, because the uninephrectomy necessary to induce a severe hypertension was not performed. However, the procedure employed is sufficient to strongly upregulate cardiac NP gene expression. 
A

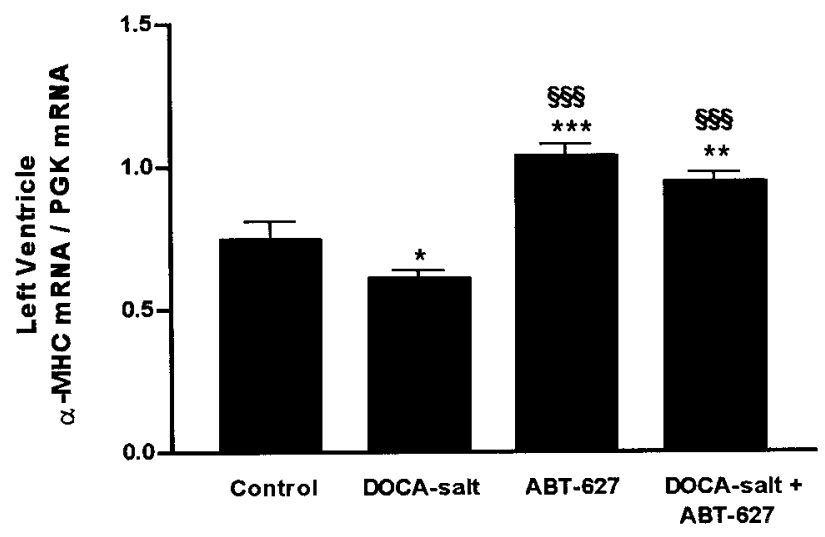

B



Fig. 3. Relative abundance of $\alpha$-myosin heavy chain (MHC) transcripts in the left $(A)$ and right $(B)$ ventricles after chronic $\mathrm{ET}_{\mathrm{A}}$ receptor blockade $\left(10 \mathrm{mg} \cdot \mathrm{kg}^{-1} \cdot\right.$ day $^{-1}$ of ABT-627) in DOCA-salt hypertensive rats. Values are means $\pm \mathrm{SE}$. $* P<0.05$, $* * P<0.01$, and $* * * P<0.001$ vs. control; $\$ P<0.05$ and $\$ \S \S P<0.001$ vs. DOCA-salt $(n=4-5)$.

Blockade of the $\mathrm{ET}_{\mathrm{A}}$ receptor resulted in a significant reduction of blood pressure, suggesting a role for ET-1 in the development of this type of hypertension. Moreover, rats receiving the $\mathrm{ET}_{\mathrm{A}}$ blocker alone exhibited lower blood pressure than control rats. The latter observation supports a role for ET-1 in the regulation of blood pressure under physiological conditions. Reduction of blood pressure in control animals has also been reported after the administration of the selective $\mathrm{ET}_{\mathrm{A}}$ antagonist FR-139317 (4).

ANF and BNP gene expression was increased in both ventricles as well as in the left atria of DOCA-salttreated rats, confirming our previous findings (25). $\mathrm{ET}_{\mathrm{A}}$ blockade partially prevented the increase in transcript concentration induced by DOCA-salt in the left ventricle and totally prevented it in the right ventricle. Neither ANF nor BNP atrial mRNA levels were affected by ABT-627. In control animals, the administration of the $\mathrm{ET}_{\mathrm{A}}$ antagonist decreased ANF and BNP gene expression in the left ventricle, suggesting that ET-1 plays a role in the regulation of $\mathrm{BNP}$ gene expression in the ventricles but not in the atria. Furthermore, these findings suggest that ET-1 participates in the maintenance of NP gene expression under physiological con- ditions, because control rats treated with the blocker alone showed significantly lower NP mRNA levels in the left ventricle. It is not clear whether this is a purely humoral effect, because the control rats treated with the $\mathrm{ET}_{\mathrm{A}}$ blocker had significantly lower blood pressure levels than control animals. Although blockade of the $\mathrm{ET}_{\mathrm{A}}$ receptor led to a dramatic reduction of NP transcript concentration in the left ventricle of DOCA-salt animals, it was not reduced to basal levels, suggesting that factors other than ET-1 may participate in the regulation and maintenance of the enhanced NP expression in chronic hemodynamic overload. This is in line with our previous studies using the angiotensinconverting enzyme (ACE) inhibitor ramipril. These studies showed that there are two components that determine ventricular NP concentration and transcript levels: one is an ACE inhibitor-sensitive component that accompanies anatomical hypertrophy, and the other is a component that is dependent on hemodynamic load (16). Under normal conditions, ANF is secreted by the atria and BNP is released mainly by the ventricles $(17,27)$. However, with chronic volume or pressure overload, the ventricles actively produce and release both ANF and BNP. Circulating levels of

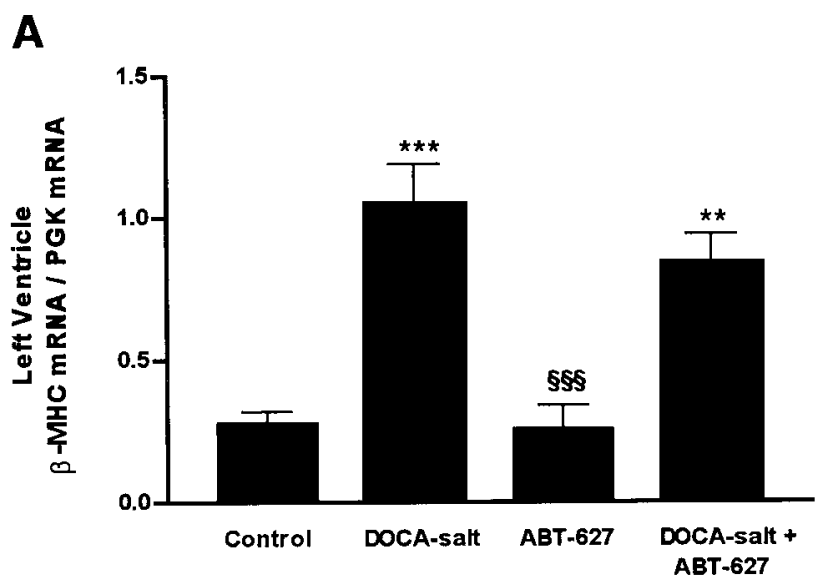

B

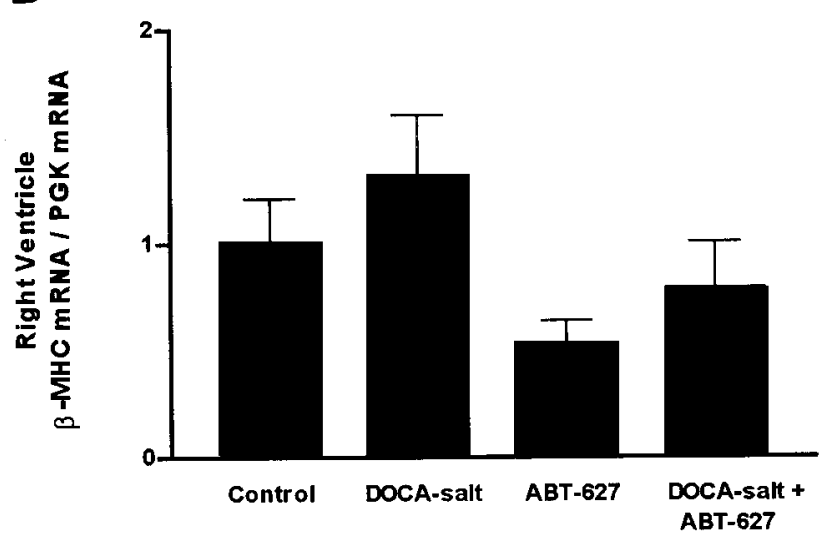

Fig. 4. Relative abundance of $\beta$-MHC transcripts in the left $(A)$ and right $(B)$ ventricles after chronic $\mathrm{ET}_{\mathrm{A}}$ receptor blockade $(10 \mathrm{mg}$. $\mathrm{kg}^{-1} \cdot$ day $^{-1}$ of ABT-627) in DOCA-salt hypertensive rats. Values are means \pm SE. ${ }^{* *} P<0.01$ and ${ }^{* * *} P<0.001$ vs. control; $\S \S \S P<0.001$ vs. DOCA-salt $(n=4-5)$. 
A

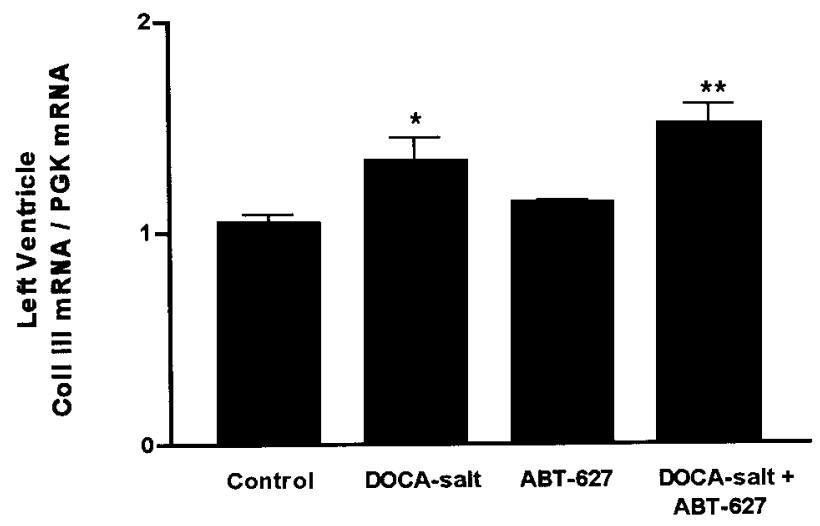

B



Fig. 5. Relative abundance of collagen III (Coll III) transcripts in the left $(A)$ and right $(B)$ ventricles after chronic $\mathrm{ET}_{\mathrm{A}}$ receptor blockade $\left(10 \mathrm{mg} \cdot \mathrm{kg}^{-1} \cdot\right.$ day $^{-1}$ of ABT-627) in DOCA-salt hypertensive rats. Values are means \pm SE. $* P<0.05$ and $* * P<0.01$ vs. control $(n=$ $4-5)$.

$\mathrm{ANF}$ and BNP were elevated in DOCA-salt-treated rats, which is in line with previous investigations (25). The increase in circulating BNP was considerably higher than that of $\mathrm{ANF}$ (46\% vs. $18 \%$ ). $\mathrm{ET}_{\mathrm{A}}$ receptor blockade resulted in a reduction of plasma ANF and BNP to near control levels. The decrease in circulating $\mathrm{NP}$ induced by the $\mathrm{ET}_{\mathrm{A}}$ antagonist was mirrored by changes in ventricular NP gene expression and content, as well as by changes in blood pressure. DOCAsalt-treated rats that were also treated with the $\mathrm{ET}_{\mathrm{A}}$ antagonist were normotensive. These results suggest that the reduction of circulating NP in DOCA-salttreated rats that were also treated with ABT-627 may be the result of the reduction of NP gene expression as well as the normalization of blood pressure promoted by $\mathrm{ET}_{\mathrm{A}}$ blockade. Such association between NP gene expression and circulating NP levels has also been reported in renovascular hypertension (11). DOCAsalt-treated rats exhibited a significant reduction of irANF in both atria and an increase in the right and left ventricles. The reduction of irANF in the right atria was not accompanied by an increase in ANF gene expression as it occurs in the left atria. We have previously observed a similar depletion of ANF stores without increase in mRNA steady-state levels during mineralocorticoid escape. Continued mineralocorticoid treatment, however, resulted in increased mRNA levels (26). These studies and the investigations reported here indicate that despite the upregulation of ET-1 gene expression, ANF mRNA levels rise only after a critically diminished level of stored hormone is reached. In contrast, ventricular irANF as well as mRNA levels were increased in DOCA-salt hypertensive rats and significantly reduced by $\mathrm{ET}_{\mathrm{A}}$ receptor blockade. These changes were reflected in the circulating levels of ANF, suggesting that ET-1 plays a significant role in the regulation of ANF production and gene expression in the ventricles but not in the atria.

In DOCA-salt-treated rats, BNP content was not modified in either left or right atria; in contrast, it was increased in both ventricles and reduced by $\mathrm{ET}_{\mathrm{A}}$ receptor blockade. Changes in BNP gene expression were accompanied by similar changes in irBNP in both ventricles. Moreover, these changes were reflected in circulating BNP levels. These findings suggest that the majority of circulating BNP is derived from the ventricles and that the synthesis and release of this NP is regulated by ET-1.

A significant left ventricular hypertrophy occurred in DOCA-salt-treated rats, which was partially reduced by the $\mathrm{ET}_{\mathrm{A}}$ receptor blockade. The potential role of ET-1 in the development and maintenance of cardiac hypertrophy is strongly supported by the fact that ET-1 is a potent growth-promoting factor: it induces DNA synthesis and proliferation of smooth muscle cells, fibroblasts, and hypertrophy of cardiocytes (7, 15). $\mathrm{ET}_{\mathrm{A}}$ and $\mathrm{ET}_{\mathrm{B}}$ receptors have been implicated in the pathogenesis of myocardial hypertrophy $(13,15)$. In cultured ventricular myocytes, incorporation of phenylalanine into cellular protein in response to ET-1 has been reported to be significantly attenuated in the presence of selective antagonists for $\mathrm{ET}_{\mathrm{A}}$ and $\mathrm{ET}_{\mathrm{B}}$ receptors (13). Because both receptors have been implicated in the pathogenesis of left ventricular hypertrophy, this could account for the fact that the admin-

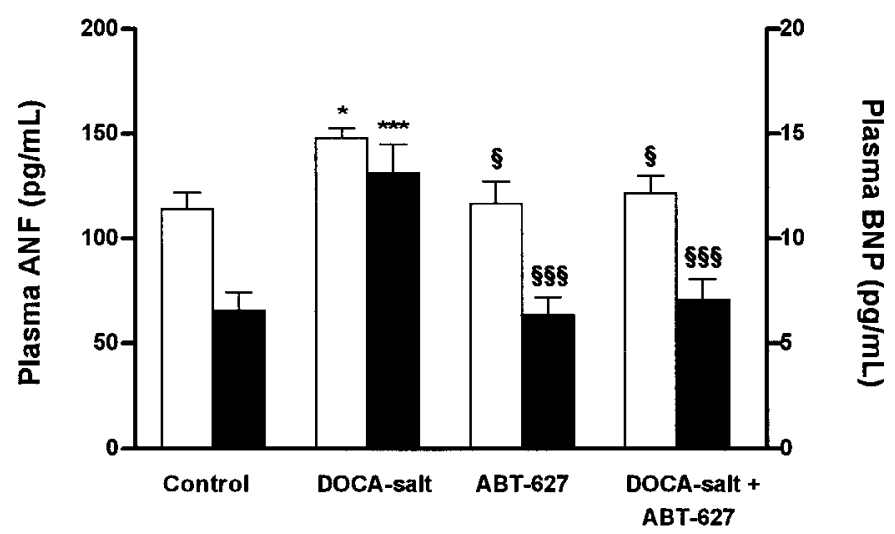

Fig. 6. Plasma ANF (open bars) and BNP (filled bars) after $\mathrm{ET}_{\mathrm{A}}$ receptor blockade $\left(10 \mathrm{mg} \cdot \mathrm{kg}^{-1} \cdot \mathrm{day}^{-1}\right.$ of ABT-627) in DOCA-salt hypertensive rats. Values are means \pm SE. $* P<0.05$ and $* * * P<$ 0.001 vs. control; $\S P<0.05$ and $\S \S \S P<0.001$ vs. DOCA-salt $(n=$ 10-12). 
A



C

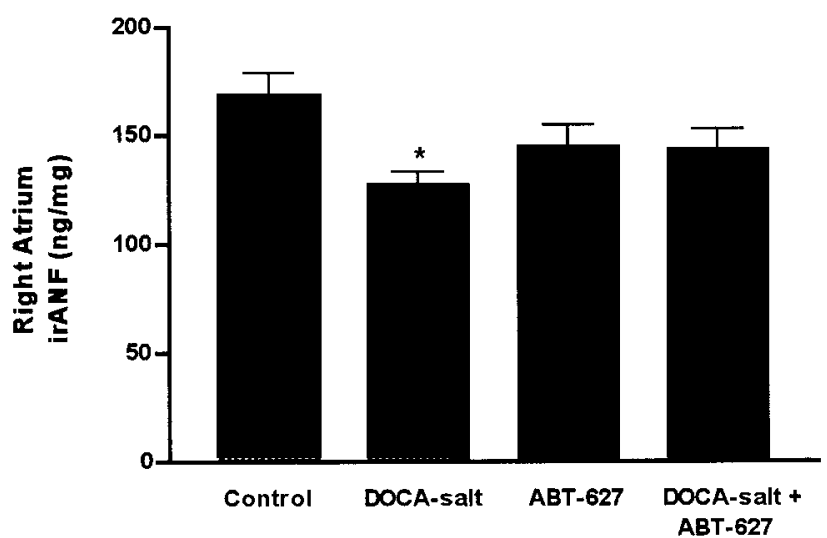

B

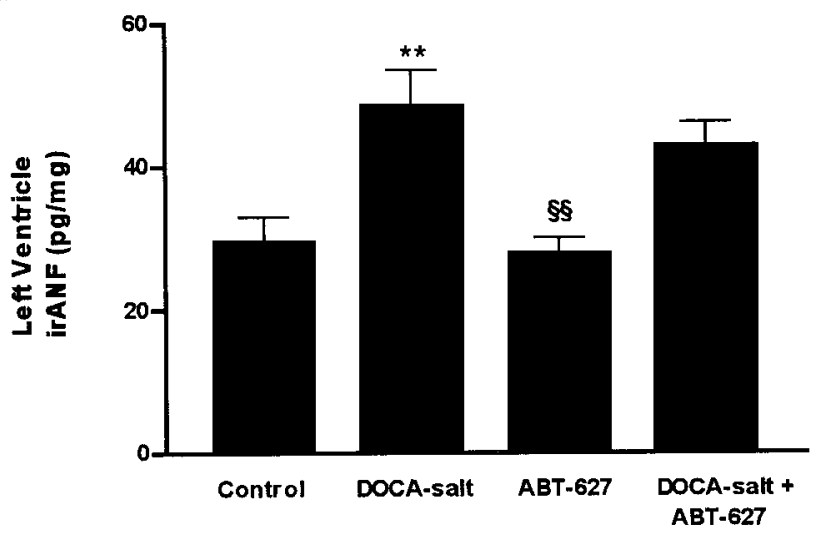

D

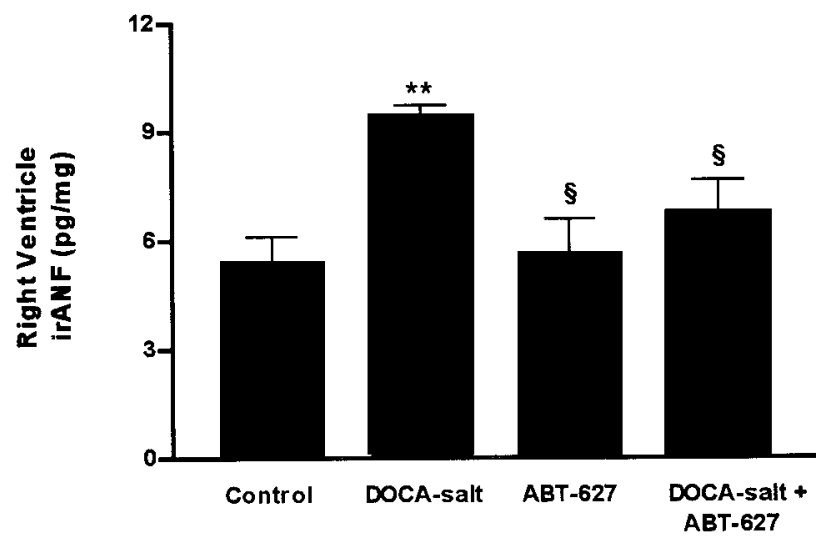

Fig. 7. Cardiac immunoreactive (ir) $\mathrm{ANF}$ after chronic $\mathrm{ET}_{\mathrm{A}}$ receptor blockade $\left(10 \mathrm{mg} \cdot \mathrm{kg}^{-1} \cdot \mathrm{day}^{-1}\right.$ of $\left.\mathrm{ABT}-627\right)$ in DOCA-salt hypertensive rats. $A$ : left atrium; $B$ : left ventricle; $C$ : right atrium; and $D$ : right ventricle. Values are means $\pm \mathrm{SE} . * P<0.05$ and $* * P<0.01$ vs. control; $\$ P<0.05$ and $\$ \S P<0.01$ vs. DOCA-salt $(n=4-5)$.

istration of a highly selective $\mathrm{ET}_{\mathrm{A}}$ blocker causes only a partial regression of left ventricular hypertrophy in the DOCA-salt-treated rat. However, the administration of bosentan $\left(\mathrm{ET}_{\mathrm{A}} / \mathrm{ET}_{\mathrm{B}}\right.$ receptor antagonist) also causes partial regression of left ventricular hypertrophy in the same experimental model. In aortic-banded rats, the treatment with $\mathrm{BQ}-123$, a selective $\mathrm{ET}_{\mathrm{A}}$ blocker, induced regression of hypertrophy after $1 \mathrm{wk}$ of banding, although the effect was no longer evident after 2 wk of banding (8). From these findings it was concluded that ET-1 might be relevant in triggering rather than in maintaining the hypertrophic response to hemodynamic overload. In the present study, however, a partial regression of ventricular hypertrophy was evident even after $5 \mathrm{wk}$ of treatment with the antagonist. Taken together, these results support a role for ET-1 not only in triggering but also in the maintenance of cardiac hypertrophy. Partial regression of left ventricular hypertrophy in the presence of ET-1 antagonisms strongly supports the participation of other factors in the cardiac hypertrophic response to hemodynamic overload. Several reports support the existence of a cross-talk interaction between ANG II and ET-1 in the hypertrophic response. ANG II would thus stimulate (through the ANG II type 1 , or $\mathrm{AT}_{1}$ receptor) ET-1 gene expression and content in the heart and in blood vessels $(6,14)$. Moreover, ET-1 receptor antagonists inhibit the mitogenic effect of ANG II on cardiomyocytes and blood vessels (14). Furthermore, $\mathrm{A}_{1}$ receptor antagonists reduce ET-1 overexpression in renin transgenic rats (23).

Ventricular hypertrophy is characterized by the reexpression of the cardiac fetal gene program, which includes modifications in MHC content. In the present study, DOCA-salt treatment induced a relative increase in $\beta$-MHC gene expression and a decrease in $\alpha$-MHC transcript abundance. $\mathrm{ET}_{\mathrm{A}}$ receptor blockade did not change $\beta$-MHC expression, but it increased $\alpha$-MHC gene expression, suggesting that ET-1 selectively regulates $\alpha$-MHC gene expression. In the present study, neither anatomic hypertrophy nor MHC isoform switch occurred in the right ventricle, but 
A

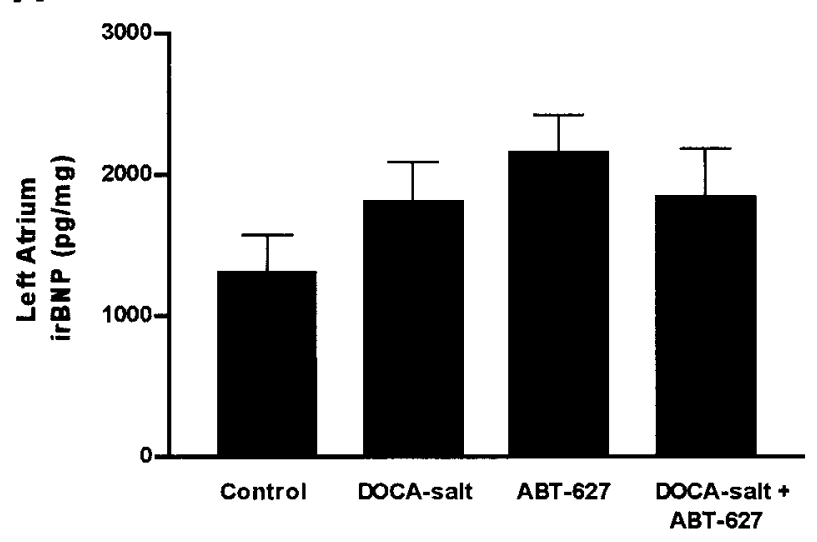

C

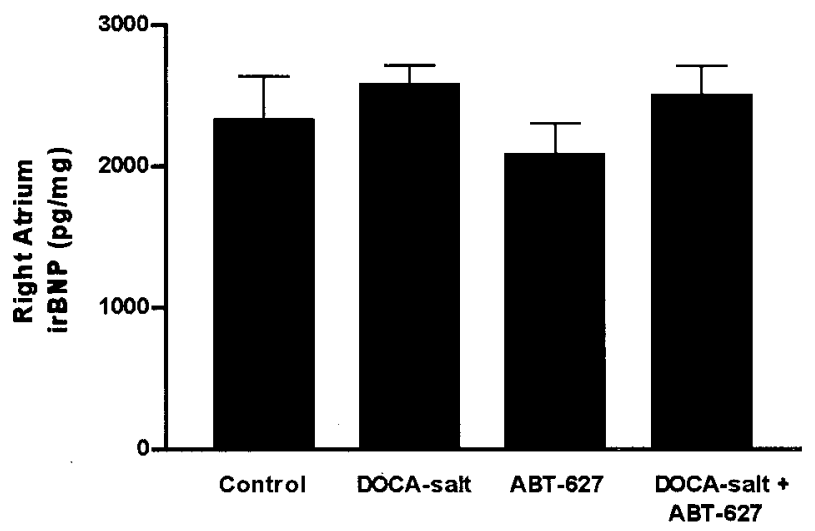

B

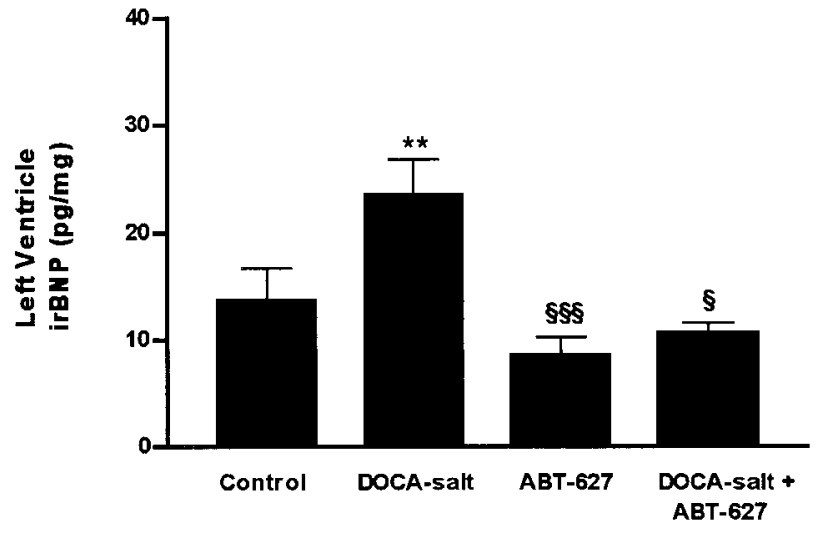

D

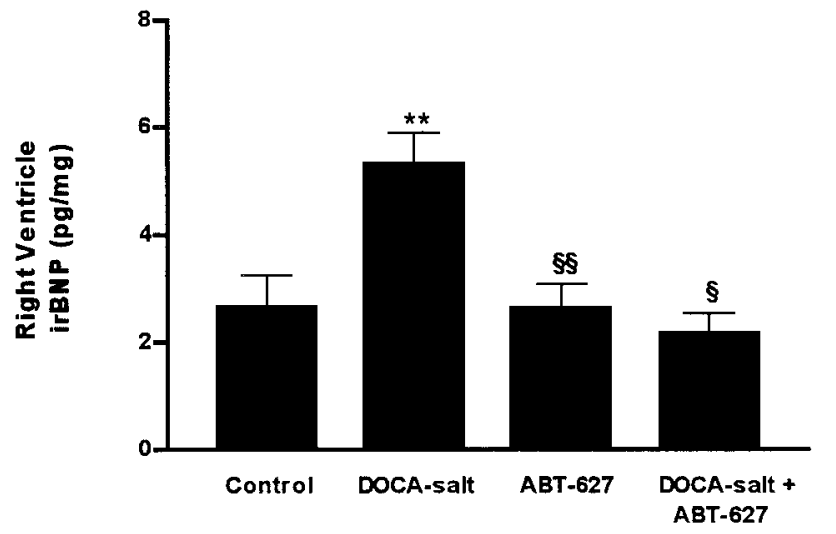

Fig. 8. Cardiac irBNP after chronic $\mathrm{ET}_{\mathrm{A}}$ receptor blockade $\left(10 \mathrm{mg} \cdot \mathrm{kg}^{-1} \cdot \mathrm{day}^{-1}\right.$ of ABT-627) in DOCA-salt hypertensive rats. $A$ : left atrium; $B$ : left ventricle; $C$ : right atrium; $D$ : right ventricle. Values are means $\pm \mathrm{SE}$. ${ }^{*} P<<$ 0.01 vs. control; $\S P<0.05$, $\S \S P<0.01$, and $\S \S P<0.001$ vs. DOCA-salt $(n=4-5)$.

there was an enhancement of NP gene expression. We previously reported similar findings in renovascular hypertensive rats (16); i.e., increased right ventricular NP gene expression without either anatomic hypertrophy or MHC isoform switch. These findings support the view that enhanced NP gene expression may coexist with hypertrophy but that it is not necessarily dependent on this process. During cardiac hypertrophy progression, fibrillar collagen content of the ventricle increases as the result of the activation of interstitial fibroblasts. In the present investigation, collagen III gene expression was markedly increased in the left ventricle, but it was not affected by $\mathrm{ET}_{\mathrm{A}}$ receptor blockade. This finding suggests that ET-1 does not signal through the $\mathrm{ET}_{\mathrm{A}}$ receptor in the activation of cardiac fibroblasts responsible for the increased collagen III production. Cardiac fibroblasts have been reported to possess $\mathrm{ET}_{\mathrm{A}}$ and $\mathrm{ET}_{\mathrm{B}}$ receptor subtypes, the latter being predominant (10). Both ET-1 and ET-3 were reported to be similar in their ability to stimulate the synthesis of fibrillar collagen, which suggests the in- volvement of both types of receptors, because the $\mathrm{ET}_{\mathrm{A}}$ receptor is selective for ET-1 (5). However, the utilization of PED-3512-PI, a specific antagonist for the $\mathrm{ET}_{\mathrm{A}}$ receptor, failed to suppress the stimulatory effect of ET-1 on collagen synthesis (5). In conclusion, our results show that in DOCA-salt hypertension, ET-1 plays a role in the regulation of chronically enhanced NP gene expression and production in the ventricles, but not in the atria, and this suggests the participation of other regulating factors. ET-1 is also a mediator in the development of hypertension and ventricular hypertrophy and in the downregulation of $\alpha$-MHC expression. Our findings further support the hypothesis that although ventricular hypertrophy, enhanced NP production, and MHC isoform switch are present in chronic hemodynamic load, they are processes that can be dissociated and seem to be differentially regulated. Furthermore, NP synthesis and production in the atria appear to be regulated by changes in the hemodynamic load rather than by changes in the endocrine environment. Ventricular synthesis and production of NP, on 
the other hand, appear to be influenced by the cardiac neurohormonal environment.

We thank Dr. T. Opgenorth from Abbot Laboratories for the generous supply of the $\mathrm{ET}_{\mathrm{A}}$ antagonist and Michelle Stevenson, Amalia Ponce, and Carole Frost for excellent technical assistance.

This work was supported by the Ontario Heart and Stroke Foundation and the Medical Research Council of Canada.

\section{REFERENCES}

1. Bruneau BG and de Bold AJ. Selective changes in natriuretic peptide and early response gene expression in isolated rat atria following stimulation by stretch or endothelin-1. Cardiovasc Res 28: 1519-1525, 1994.

2. Cameron VA, Aitken GD, Ellmers LJ, Kennedy MA, and Espiner EA. The sites of gene expression of atrial, brain, and C-type natriuretic peptides in mouse fetal development: temporal changes in embryos and placenta. Endocrinology 137: 817824, 1996.

3. Chien KR, Knowlton KU, Zhu H, and Chien S. Regulation of cardiac gene expression during myocardial growth and hypertrophy: molecular studies of an adaptative physiologic response. FASEB J 5: 3037-3046, 1991.

4. Fujita K, Matsumura Y, Kita S, Miyazaki Y, Hisaki K, Takaoka M, and Morimoto S. Role of endothelin-1 and the $\mathrm{ET}_{\mathrm{A}}$ receptor in the maintenance of deoxycorticosterone acetatesalt induced hypertension. Br J Pharmacol 114: 925-930, 1995.

5. Guarda E, Katwa LC, Myers PR, Tyagi SC, and Weber KT. Effects of endothelins on collagen turnover in cardiac fibroblasts. Cardiovasc Res 27: 2130-2134, 1993.

6. Ito H, Hirata Y, Adachi S, Tanaka M, Tsujino M, Koike A, Nogami A, Murumo F, and Hiroe M. Endothelin-1 is an autocrine/paracrine factor in the mechanism of angiotensin IIinduced hypertrophy in cultured rat cardiomyocytes. $J$ Clin Invest 92: 398-403, 1993.

7. Ito H, Hirata Y, Hiroe M, Tsujino M, Adachi S, Takamoto T, Nitta M, Taniguchi K, and Marumo F. Endothelin-1 induces hypertrophy with enhanced expression of muscle-specific genes in cultured neonatal rat cardiomyocytes. Circ Res 69: 209-215, 1991.

8. Ito H, Hiroe M, Hirata Y, Fujisaki H, Adachi S, Akimoto H, Ohta Y, and Marumo F. Endothelin $\mathrm{ET}_{\mathrm{A}}$ receptor antagonist blocks cardiac hypertrophy provoked by hemodynamic overload. Circulation 89: 2198-2203, 1994.

9. Itoh H, Nakao K, Mukoyama M, Arai H, Yamada T, Saito Y, Shiono S, Hosoda K, Shirakami G, and Suga S. Pathophysiological role of augmented atrial natriuretic polypeptide gene expression in DOCA-salt hypertension: effects of atrial natriuretic polypeptide monoclonal antibody. Am J Hypertens 4: 3944, 1991.

10. Katwa LC, Guarda E, and Weber KT. Endothelin receptors in cultured rat cardiac fibroblasts. Cardiovasc Res 27: 2125-2129, 1993.

11. Kawarami H, Okayama H, Hamada C, and Hiwada K. Alteration of atrial natriuretic peptide and brain natriuretic peptide gene expression associated with progression and regression of cardiac hypertrophy in renovascular hypertensive rats. Clin Sci (Colch) 90: 197-204, 1996.

12. Larivière R, Deng LY, Day R, Sventek $P$, Thibault G, and Schiffrin EL. Increased endothelin-1 gene expression in the endothelium of coronary arteries and endocardium in the DOCAsalt hypertensive rat. J Mol Cell Cardiol 27: 2123-2131, 1995.

13. Molenaar P, O'Rally G, Sharkey A, Kuc RE, Harding DP, Plumpton C, Gresham GA, and Davenport AP. Character- ization and localization of endothelin receptor subtypes in the human atrioventricular conducting system and myocardium. Circ Res 72: 526-538, 1993.

14. Moreau P, d'Uscio LV, Shaw S, Takase H, Barton M, and Luscher TF. Angiotensin-II increases tissue endothelin and induces vascular hypertrophy: reversal by $\mathrm{ET}_{\mathrm{A}}$ receptor antagonist. Circulation 96: 1593-1597, 1997.

15. Mullan DM, Bell D, Elso EJ, and McDermott BJ. Involvement of endothelin $\mathrm{ET}_{\mathrm{A}}$ and $\mathrm{ET}_{\mathrm{B}}$ receptors in the hypertrophic effect of ET-1 in rabbit ventricular cardiomyocytes. J Cardiovasc Pharmacol 29: 350-359, 1997.

16. Ogawa T, Linz W, Stevenson M, Bruneau BG, Kuroski de Bold ML, Chen JH, Eid H, Schölkens BA, and de Bold AJ. Evidence for load-dependant and load-independent determinants of cardiac natriuretic peptide production. Circulation 93: 2059-2067, 1996.

17. Ogawa Y, Nakao K, Mukoyama M, Hosoda K, Shirakami G, Arai H, Saito Y, Suga S, Jougasaki M, and Imura H. Natriuretic peptides as cardiac hormones in normotensive and spontaneously hypertensive rats: the ventricle is a major site of synthesis and secretion of brain natriuretic peptide. Circ Res 69: 491-500, 1991.

18. Opgenorth TJ, Adler A, Calzadilla SV, Chiou WJ, Dayton DB, Dixon DB, Gehrke LJ, Hernandez L, Magnusson BR, Marsh KC, Novosad EI, Von Geldern T, Wessale JL, Winn M, and Wu-Wong JR. Pharmacological characterization of A-127722: an orally active and highly potent $\mathrm{ET}_{\mathrm{A}}$-selective receptor antagonist. J Pharmacol Exp Ther 276: 473-481, 1996.

19. Sarda IR, de Bold ML, and de Bold AJ. Optimization of atrial natriuretic factor radioimmunoassay. Clin Biochem 22: 11-15, 1989.

20. Sarda IR, Wigle DA, Flynn TG, and Pang SC. Radioimmunoassay for rat B-type natriuretic peptide (BNP-45). J Immunoassay 14: 167-182, 1992.

21. Schwartz K, Boheler K, de la Bastie D, Lompre AM, and Mercadier JJ. Switches in cardiac muscle gene expression as a result of pressure and volume overload. Am J Physiol Regulatory Integrative Comp Physiol 262: R364-R369, 1992.

22. Suzuki E, Hirata Y, and Kohmoto O. Cellular mechanisms for synthesis and secretion of atrial natriuretic peptide and brain natriuretic peptide in cultured rat atrial cells. Circ Res 71: 1039-1048, 1992.

23. Stula M, Pinto YM, Gschwend S, Teisman AC, van Gilst WH, Bohm M, Dietz R, and Paul M. Interaction of the reninangiotensin system and the endothelin system in cardiac hypertrophy. J Cardiovasc Pharmacol 31, Suppl: 403-405, 1998.

24. Thibault C, Doubell AF, Garcia R, Lariviere R, and Schiffrin EL. Endothelin-stimulated secretion of natriuretic peptides by rat atrial myocytes is mediated by endothelin-A receptor. Circ Res 74: 460-470, 1994.

25. Yokota N, Bruneau BG, Fernandez BE, Kuroski de Bold ML, Piazza LA, Eid H, and de Bold AJ. Dissociation of cardiac hypertrophy, myosin heavy chain isoform expression, and natriuretic peptide production in DOCA-salt rats. Am J Hypertens 8: 301-310, 1995.

26. Yokota N, Bruneau BG, Kuroski de Bold ML, and de Bold AJ. Atrial natriuretic factor significantly contributes to the mineralocorticoid escape phenomenon: evidence for a guanylate cyclase-mediated pathway. J Clin Invest 94: 1938-1946, 1994.

27. Vollmar AM and Schulz R. Evidence for the presence of ANP-precursor material in the rat thymus. Biochem Biophys Res Commun 155: 700-708, 1988. 